\title{
Bond Market Mania
}

\author{
Christopher J. Neely
}

A s the figure's top panel shows, U.S. 10-year Treasury note (bond) yields have been very volatile since May. Yields fell more than 75 basis points from May 1 to their nadir June 13, before soaring-more than 125 basis points-after the FOMC's June 25 statement. Many financial analysts blame the Fed's announcements for this disorder. For example, the FOMC announcement of May 6 was widely interpreted to herald sustained lower short-term rates and/or the purchase of long-term bonds by the Fed to effect "easier" monetary policy: "...the probability of an unwelcome substantial fall in inflation, though minor, exceeds that of a pickup in inflation from its already low level." In contrast, the financial press interpreted a less-than-expected federal funds target cut and an almost identical press release following the June 25 FOMC meeting to mean that the Fed was reversing course by playing down the possibility of a fall in inflation.

How might the Fed's announcements have influenced bond yields? There are two major components to current U.S. Treasury yields: expected inflation and a real component. Higher expected inflation raises interest rates because lenders demand compensation for the expected loss of purchasing power. But the real rate depends on the expected productivity of physical capital. A robust economy and high productivity encourage businesses to borrow to finance future production, bidding up interest rates.

Did the Fed's statements influence bond yields by changing expectations of inflation, real activity, or both? Although we cannot directly observe the components of long-term interest rates, we can estimate real interest rates from the yields on Treasury inflation-indexed securities (TIIS). The principal and coupon payments on TIIS are indexed to the CPI to protect investors from inflation. Thus, the usual interpretation is that projected inflation is reflected in ordinary bond yields but has no effect on TIIS yields, and the market's forecast of inflation is approximately the difference between these yields. Complicating this calculation, however, is the fact that deflation does not reduce TIIS principal payments; a higher probability of deflation will reduce TIIS yields. The probability of cumulative deflation over a ten-year period must be low, so TIIS yields probably still mostly reflect real returns.

The first two panels of the figure show that from May through July, U.S. real interest rates (10-year TIIS yields) moved almost as much as 10-year nominal yields. Unless expectations of cumulative deflation changed dramatically, forecasts of real growth drove most of the fluctuations in Treasury yields. This conclusion chal-

lenges the interpretation that Fed statements caused the bond market volatility by changing inflation expectations.

The figure also shows that nominal and real yields in the United Kingdom followed much the same pattern as that in the United States, which bolsters the interpretation that changes in forecasts of real returns-rather than greater expectations of deflation-drove the fluctuations in U.S. bond yields. Trade and financial markets link economic activity and real interest rates in the U.S. and the U.K.

The bottom panel shows expected inflation as the difference between nominal yields and inflation-indexed yields for the U.S. and the U.K. As the first two panels imply, expected U.S. inflation fell much less than the U.S. real rate, slipping only about 20 basis points from April to mid-June, before rising again. Expected inflation in the U.K. showed no trend over this period, however, probably due to the Bank of England's explicit 2.5 percent inflation target.

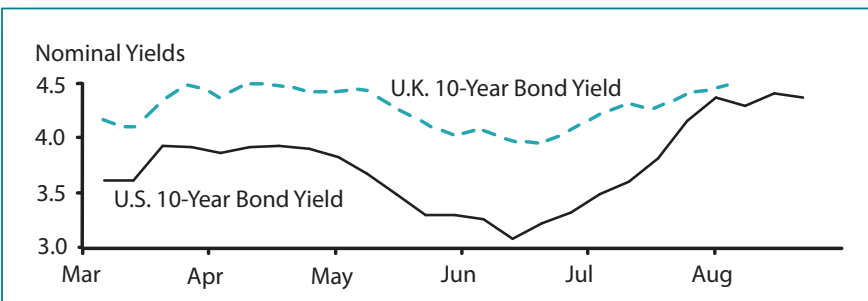

Inflation-Indexed Yields

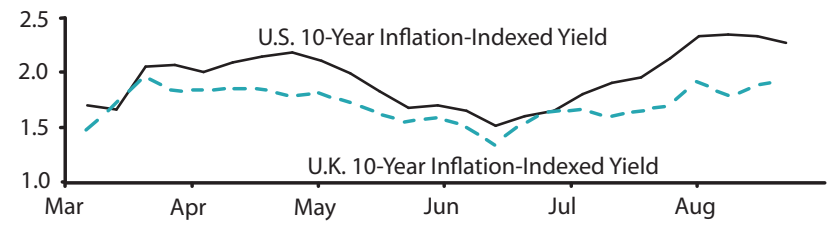

Expected Inflation

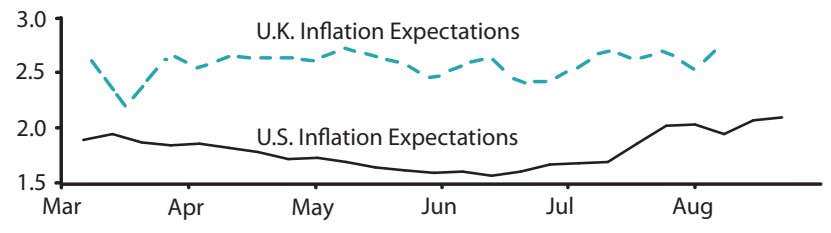

SOURCE: Data are from Bloomberg and the Board of Governors of the Federal Reserve System. 